\title{
Horváth G. K. (szerk.) (2014): Víz és társadalom Magyarországon a középkortól a XX. század végéig (Balassi Kiadó, Budapest, 725 o.)
}

\author{
KŐRÖS ÁKOS
}

\begin{abstract}
KőRös Ákos: PhD-hallgató, Szent István Egyetem, Enyedi György Regionális Tudományok Doktori Iskola; 2103 Gödöllő, Páter Károly u. 1.; koros.akos@icloud.com; https://orcid.org/0000-0001-9851-4752
\end{abstract}

\begin{abstract}
Ákos KöRös: PhD student, Enyedi György Doctoral School of Regional Sciences, Szent István University; Páter Károly u. 1., H-2103 Gödöllo", Hungary; koros.akos@icloud.com; https://orcid.org/00000001-9851-4752
\end{abstract}

A Horváth Gergely Krisztián szerkesztésében 2014-ben megjelent tanulmánykötetnek kalandos előélete volt. Vári András, kiváló magyar társadalomtörténész 2011-ben elnyerte az Országos Tudományos Kutatási Alap támogatását, de a kutatási program végrehajtását korai halála megakadályozta. Kollégája, Horváth Gergely Krisztián vezetésével sikeresen lezárult program eredményeit mutatja be e könyv, melyben emléket állítanak Vári András munkásságának is.

A kötetben tizenkilenc szerző tizenhat tanulmánya és hét forrás közlése található. A szerzők zöme társadalomkutató, többségük történész. A kutatás utolsó nekilendülése már az alapvetően közgazdasági profilú Hétfa Kutatóintézet berkein belül zajlott le, ez magyarázza, hogy a tanulmányok egy része közgazdasági megközelítésű. A tudományos fokozattal rendelkező szerzők művei mellett kétkét mesterszakos hallgató és doktorandusz tanulmánya is bekerült a kötetbe.

A tanulmánykötet szerzői a magyarországi társadalom és a vizek kapcsolatát elemzik történeti perspektívában. A kötet regionális fókuszában NyugatMagyarország van: a Lajta, a Duna magyarországi felső szakasza és a Rába vízgyűjtő területe, de szó esik a Tiszáról is, illetve egy-egy tanulmány foglalkozik Erdéllyel, a Völgységgel és Észak-Magyarországgal.

Az első tanulmány rendhagyó módon interdiszciplináris összefoglalója a kötetnek. Horváth Gergely Krisztián felhasználta a Hétfa Kutatóintézet közgazdasági tudását és tapasztalatát a történeti tanulmányok értelmezéséhez. A szerkesztők - az elemzési módszerek bemutatása után - négy csoportba osztották a kötet tanulmányait:

- Az első csoportba sorolt tanulmányok a vízhasználat és a tulajdonok, tulajdonjogok kapcsolatával foglalkoznak. Vajda Tamás malmokról írt ta-

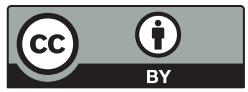


nulmánya jogtörténeti vizsgálaton keresztül mutatja be a korabeli vállalkozók egy csoportjának társadalmi-gazdasági környezetét. Gálffy László a Duna Bécs és Buda közötti szakaszához kapcsolódó városok és kisebb települések viszonyát elemzi, és nem meglepő módon megállapítja, hogy a part mentén élők mozgásterének szerves része volt a folyó. Tulajdon- és haszonjellege volt a folyónak, amely nem elválasztotta, hanem szövetségbe fogta össze a part menti településeket. Hasonló következtetésre jut Rácz Lajos, aki környezettörténeti tanulmányában a pest-budai ideiglenes hidak adatai alapján a kis jégkorszak utolsó időszakának teleit vizsgálja, és azt hangsúlyozza, hogy a rendszeresen befagyó Duna összekapcsolta az akkor még különálló két várost. Vadas András tanulmányában a 17. századi török háborúk Rába menti harcászatát, a vizes térszínekre alapozott védekezést és a korabeli életet mutatja be.

- A második csoportba került két tanulmány a folyók szabályozásával - Horváth Gergely Krisztián a Lajta, Deák András a Tisza szabályozásával, annak előzményeivel és az építkezés kezdeti fázisaival - foglalkozik. Mindkét tanulmány gazdag forrásbázisra épül, az előbbi inkább az előzményekre és a közösségi cselekvés mögött rejlő személyes érdekek elemzésére fókuszál, míg az utóbbi a történeti eseményekre. Talán ebbe a körbe illett volna még Simonkay Mártonnak a Rába-szabályozással kapcsolatos tanulmánya is.

- A következö csoportot azok a tanulmányok alkotják, amelyek a vizek és az állam kapcsolatát kutatják. Máté Gábor egy szűkebb terület, a Völgységi-patak felső folyásának vízhasználati vizsgálatát végezte el, míg Ö. Kovács József országos szinten foglalkozott az állam és a vizek kapcsolatával. Mindkét tanulmány a 20. század első feléről szól, vagyis a jelenlegi településfejlesztések elözményeiként is olvashatók. Ebbe a csoportba kerülhetett volna még Pál Viktor értékelése a szocialista korszak iparosításának környezetvédelmi szempontjairól.

- A negyedik csoport tanulmányai a folyóvizek történetét politikai gazdaságtani perspektívából közelítik meg. Dominkovics Péter a vízgazdálkodás korai szakaszát vizsgálja. Megállapítja, hogy a 17. századi vármegyék adminisztrációja aktívan foglalkozott a vízhez kapcsolható jogi kérdésekkel. Balaton Petra székelyföldi regionális nagy léptékű elemzése a talajjavítási munkálatok és a víz agrártársadalomra gyakorolt hatásait vizsgálja. Bodovics Éva Miskolc városának árvizek elleni sikeres védekezéseit elemzi.

Még két tanulmányt érdemes kiemelni. Szalontai Csaba Szeged városának elhelyezkedését és a környező lápokhoz, folyókhoz és tavakhoz való viszonyrendszerét elemzi. Bagi Zoltán, Vadas Andráshoz hasonlóan, hadtörténeti témát dolgoz fel: vajon egy-egy hadjárat kimenetelét hogyan befolyásolhatta a vízhálózat a tizenöt éves háborúban (1591-1606)?

Az igényes kivitelü címlap, a jól szerkesztett ábrák, diagramok, a kötet végén található színes képek, térképek, valamint a Takács Árpád által elkészített földrajzi névmutató a szerzők és a szerkesztők magas színvonalú munkáját bizonyítják. 